\title{
What's News: A Progressive Framework for Evaluating the International Debate Over the News
}

\section{Jonathan Graubart $\dagger$}

The news media has long been a popular target of criticism. In 1970, Vice President Spiro Agnew lashed out at what he claimed was a liberal, Eastern Establishment bias in the media, referring to news journalists as "nattering nabobs of negativism." Media critics have attacked the media for being politically biased, ${ }^{2}$ shallow, and co-opted into the established institutions of power so that it is unwilling to challenge or even scrutinize the political and socioeconomic norms of our society. ${ }^{3}$

Criticizing the media is far from being only an American tradition. The most intense battles over media bias have been fought in the international forum. In the past two decades, many Third World nations ${ }^{4}$ have forcefully complained that the United States and other western nations dominate international news reporting in general and Third World news reporting in particular. These nations accuse the western nations of using their superior resources and dominant position to prevent less developed countries from forming their own news reporting capabilities. Without their own news reporting strnctures, Third World countries argue that they are unable to provide their citizens with information

$\dagger$ B.A. 1985, University of Pennsylvania; third-year student, Boalt Hall School of Law, University of California, Berkeley.

1. William Safire, currently a political columnist for the N.Y. Times, then one of President Nixon's speech writers, coined the phrase while on loan to Agnew in the fall of 1970. W. SAFIRE, SAFIRE's Political Dictionary 444-45 (3d ed. 1978).

2. For example, Reed Irvine and other right-wing critics of the press formed Accuracy In the Media (AIM), a media "watchdog" to expose the so-called liberal bias in the media.

3. Fairness and Accuracy In Reporting (FAIR), a leftist media watchdog, and a number of progressive journalists have complained of the general lack of diversity in the mainstream media and its reluctance to challenge the political norms of the society. See, e.g., M. HERTSGAARD, ON BENDED KNEE (1988) (documenting the news media's obsequious coverage of the Reagan Administration); MOTHER JONES, June/July 1987 (a special media-watch issue); Pollak, And Then There Was One (Book Review), 246 THE NATION 209 (1988).

4. The Third World refers to all of the countries in Africa, Asia, and Latin America other than Japan, Israel, the Soviet Union, and South Africa. According to UNESCO, all of these countries are less developed countries. UNESCO, STATISTICAL YEARBOOK 1982, at 1-14 (1982). 
necessary to further the country's economic, political, and cultural development.

These nations further charge that western reporting on the Third World has been shallow, overly negative, distorted, and perhaps worst of all, ethnocentric. Such reporting has produced a negative image in the international community as well as a negative self-image in many Third World countries as they are forced to rely on western news reporting for news of their own regions.

The Third World has waged its battle primarily in the United Nations (U.N.) and in the United Nations Educational, Scientific and Cultural Organization (UNESCO). There, it has proposed and passed various declarations and resolutions calling for a "New International Information Order" (NIIO). ${ }^{5}$ The NIIO calls for the international community to work actively for a more equitable balance in the international flow of information. The United States and most western nations have strongly rejected this proposed new order, preferring the existing order where international communication is based on the "free flow of information" principle. ${ }^{6}$

Although developing countries oppose the overall western domination of communication, ${ }^{7}$ they have reserved their sharpest attacks for the western domination of the news. The United States responds that the NIIO would restrict the freedom of western journalists and legitimate the presence of state-controlled media. One reason the Reagan Administration provided for withdrawing from UNESCO in 1984 was its objection to the organization's championing of the NIIO. ${ }^{8}$ U.S. withdrawal has not ended the debate over the NIIO but merely diminished the amount of news coverage given it. This action has done nothing to allay Third World concern with the role the western-dominated press plays in shaping Third World development.9

5. The NIIO does not refer to any particular declaration or resolution, but is rather one of several shorthand labels that proponents, critics, and scholars have given to the international movement to restructure the flow of information. Other labels include the New World Information Order (NWIO) and the New World International Communication Order (NWICO). No particular label seems to be dominant. For convenience, this Comment chooses the NIIO.

In addition, it should be noted that while the Third World is far from being a monolithic bloc, most of these nations support the NIIO. See infra notes 23-25 and accompanying text.

6. For a description of the "free flow of information principle," see infra notes 10-11 and accompanying text.

7. In addition to news reporting, the field of communications encompasses all television and radio broadcasts, books, films, magazines, and satellite projections. See A. MEHRA, FreE FLow of INFORMATION 51-70 (1986).

8. Staff of House Comm. on Foreign Affairs, 98th Cong., 2D Sess., Report on U.S. WITHDRAWAL FROM UNESCO 24, 31-32 (Comm. Print 1984) [hereinafter U.S. WITHDRAWAL]. Other reasons proffered included UNESCO's politicization of issues and its budgetary and management problems. Id. at 24.

9. See Jones, Press Notes, N.Y. Times, Oct. 19, 1986, $§ 1$, at 44, col. 1 (UNESCO continues to 
This Comment suggests a new framework for U.S. evaluation of proposals to alter the current one-way flow in the news. Part I summarizes the history of the international communications debate waged in the U.N. and in UNESCO. Part II reviews the sources of Third World dissatisfaction with the current international news order and sets forth the key components of the Third World's proposed solution, the NIIO. Part III describes the U.S. response to the NIIO. Finally, Part IV proposes a revised framework for formulating a U.S. response. It argues that in evaluating proposals for a NIIO, the Umited States needs to move away from pious tributes to the sanctity of a private press and pragmatically consider what steps it can take in this area to further the economic, social, and cultural conditions in the Third World.

\section{I \\ HISTORY OF THE NIIO DEBATE IN THE U.N. AND IN UNESCO}

The guiding principle in international communications since World War II has been the U.S.-inspired goal of a "free flow of information." According to this principle, "[f]reedoin of information implies the right to gather, transmit and publish news anywhere and everywhere without fetters." ${ }^{\prime 0}$ The free-flow-of-inforination principle has been defined as a necessary part of freedom of opinion and expression. Article 19 of the Universal Declaration of Huinan Rights states that freedom of expression includes "freedoin to hold opinions without interference and to seek, receive and inpart information and ideas through any media and regardless of frontiers." 11

The first inajor challenge to the free flow principle caine from the Soviet bloc in the late $1940 \mathrm{~s}^{12}$ They criticized the principle as a tool for ensuring domination of the international media by the large western news agencies. ${ }^{13}$ According to then-Soviet ambassador to the U.N. Andrei Gromyko, the promulgation of the free-flow principle:

concealed, beneath flowery phrases concerning democracy, the interests of the bankers and industrialists for whom the Wall Street exchange was the highest expression of democracy, and it described in detail how information media and the Press should be used to render effective service to the newspaper owners and the big publishing houses which exercised

sponsor studies on international communications issues including studies on the role of journalists); Krauthammer, Let it Sink: Why the U.S. Should Bail Out of the U.N., The New RePublic, Aug. 24,1987 , at 18, 22 (in calling for U.S. withdrawal from the U.N., the author notes that the U.N. just reaffirmed the principles of the NIIO in the last assembly).

10. G.A. Res. 59 (I), 1(2), U.N. GAOR Resolutions at 95, U.N. Doc. A/64/Add. 1 (1947).

11. G.A. Res. 217(III)A, 3(1) U.N. GAOR Resolutions at 71, 74-75, U.N. Doc. A/810 (1948).

12. A. MEHRA, supra note 7 , at 25 .

13. See id. 
admimistrative control over all information media in the various countries. ${ }^{14}$

The Soviet bloc favored greater state involvement in communications to ensure a more "responsible" press. ${ }^{15}$ For example, in 1947, Yugoslavia proposed a resolution in the General Assembly asking states " to take urgent legislative and other measures' to restrict the publication of 'false and tendentious reports calculated to aggravate relations between nations, provoke conflicts and incite to war." 16 As the Soviet bloc was heavily outnumbered in the U.N., they achieved inimimal legislative success in the U.N. until the 1970s when they allied themselves with the Third World nations.

In the 1970s, the Third World countries under the leadership of the Non-aligned Movement ${ }^{17}$ launched their challenge against U.S. and western domination of international communications. Instead of a free flow of information, the Third World sought a balanced flow of information which would reflect "the concerns and legitimate aspirations of the developing countries." ${ }^{18}$ Although often aligned with the Soviet bloc, their opposition to western domination was based on different motivations. The Soviet Union already possessed an enormous domestic and international commumications nifrastructure. Hence, its debate with the West was primarily an ideological one. Most Third World nations, on the other hand, had no access to sources of international communication and possessed an unsophisticated domestic communications infrastructure. ${ }^{19}$ Accordingly, their challenge to the free-flow doctrine was-and still is-primarily motivated by pragmatic concerns; for developing nations to improve their own communications systems, they must end the western doinmation of the flow of imternational coinmunications.

The developing countries' challenge to the international information order paralleled an emerging "class consciousness" among Third World nations. By the 1970s, many Third World nations had increasingly come to identify themselves with the Non-ahigned Movement. ${ }^{20}$ Accordingly, they formed a loose voting bloc within the U.N.. Given their majority status, the Third World bloc was often successful in pushing its agenda through various U.N. agencies. ${ }^{21}$

14. 3(2) U.N. GAOR (210th plen. mtg.) at 387, U.N. Doc. A/858 (1949).

15. See A. MEHRA, supra note 7, at 30 .

16. Id. at 28 (quoting from U.N. Doc. A/C.3/162).

17. The Non-aligned Movement is a group of developing countries with a common interest in reshaping the international environment to facilitate the political, economic, and cultural emancipation and development of Third World countries. See ECDC HANDBOok, DocumENTS or THE MOVEMENT OF NON-ALIGNED COUNTRIES AND THE GROUP OF 77 Introduction (1983).

18. G.A. Res. 115B, 33 U.N. GAOR Supp. (No. 45) at 74, U.N. Doc. A/33/45 (1979).

19. See infra text accompanying notes $37-40$.

20. See supra note 17.

21. By the mid-1970s, Third World nations made up over two-thirds of the full membership in 
The most notable manifestation of the Third World bloc's political strength was its politicization of UNESCO in the 1970s. Traditionally, UNESCO had confined itself to technical activities such as gathering data for other U.N. organizations and improving the means of technical cominunication. ${ }^{22}$ In the 1970 s, the Third World bloc successfully pushed UNESCO to move past purely technical activities and address its resources to policy issues of concern to developing countries. One such policy issue was the formulation of a more equitable international communication order. ${ }^{23}$ In 1972, UNESCO passed a Soviet-sponsored resolution asking the Director General of the U.N. to prepare a draft declaration on "the fundamental principles governing the use of the mass information media with a view to strengthening peace and international understanding and combating war propaganda, racialism and apartheid."24 In 1976, on the imitiative of developing countries, UNESCO organized the San Jose Conference on international communications policies.

The San Jose Conference was far more significant than the 1972 resolution because the Conference and its accompanying declaration and recominendations inarked the beginning of the First World-Third World debate over coinmunications policies. ${ }^{25}$ On one side was an overwhelming inajority of Third World nations supporting a fundamental structural change in global commumications. On the other side were the U.S. and other western countries who wanted to preserve the existing structure. In addition to western diplonatic opposition, the western media covering the San Jose Conference was highly critical of UNESCO. ${ }^{26}$ Such western diplomatic and media pressure succeeded in moderating the tone of the final declaration. Nevertheless, the Conference's recominendations marked a major challenge to the free-flow doctrine by calling for a "balanced flow" of infornation, a "right to communicate" at national and international levels, and steps to delineate the duties and responsibilities of journalists. ${ }^{27}$

the U.N. and were generally united behind the NIIO. See C. WELLS, THE U.N., UNESCO AND THE Politics OF KNOWLEDGE 81 (1987).

22. A. MEHRA, supra note 7, at 38 .

23. Id. at 38-39.

24. Gen. Conf. Res. 4.113, 17(1) U.N. UNESCO Resolutions/Recommendations at 70 (Oct.Nov. 1972).

25. See C. WELLS, supra note 21 , at 82.

26. See id. at $82-83$. Such negative coverage would continue to characterize the western media's treatment of NIIO throughout the next two decades. See, e.g., Give UNESCO a Second Chance, N.Y. Times, Oct. 25, 1987, § 4, at 22, col. 1 (editorial); Ryan, New Skirmishes in the Global Battle over Media Freedom, Christian Sci. Monitor, July 9, 1987, at 13, col. 1 (portraying move within UNESCO to hold conference as engineered by "the Soviets and their allies"); Tuchman, UNESCO Is No Guide, N.Y. Times, Jan. 22, 1984, § 4, at 23, col. 1.

27. See C. WELLS, supra note 21 , at 84 . 
In 1976, UNESCO's Director General, Amadou Mahtar M'Bow, set up the International Commission for the Study of Communication Problems (a.k.a. the "MacBride Commission") to review global communications policies. Although the MacBride Commission included representatives from the United States and other western countries as well as a representative from the Soviet Union, it generally reflected the views of the developing countries. ${ }^{28}$ In 1978, the MacBride Commission submitted an interim report concluding that the free-flow doctrine in practice served the interests of a small western elite, consisting chiefly of the western transnational news agencies and certain large multinational corporations active in advertising or in distributing their products worldwide. ${ }^{29}$ The final Report in 1980-though softer in its attack on the free-flow doctrine-still inspired western opposition by calling for less commercialization in communications, more regulation of advertising content and influence, and emphasis upon the journalist's responsibilities. ${ }^{30}$

As a concession to the West, the General Conference of UNESCO set up the International Programme for Development of Communication (IPDC) in 1980. IPDC's focus was on improving the communication infrastructures of developing countries. ${ }^{31}$ The West supported the IPDC because its focus on technical assistance to Third World nations deflected larger normative challenges to the western-dominated international communication order. Providing technical assistance to Third World countries was seen as clearly preferable to reducing commercialization in communications and regulating advertising content.

Nevertheless, disputes formed over the proper role of the IPDC. The Third World wanted it to be a general multilateral source of technical information and funding. According to this view, developing countries could obtain technical or funding assistance from the IPDC to aid them in building or improving their communication infrastructure. The United States and other western countries opposed the Third World approach because it gave the assisting country no control in selecting what programs to assist. They envisioned the IPDC as bilateral in nature, allowing western countries to provide individual assistance to those Third World countries developing communication systems acceptable to the assisting country. ${ }^{32}$

The dispute over the proper role of the IPDC was never resolved.

28. See id. at 98.

29. Id.; See The MacBride Commission, Communication Problems Today, in CRISIS IN INTERNATIONAL News 35, 37-41 (J. Richstad \& M. Anderson eds. 1981) (excerpt from the 1978 Interim Report which argues that the free flow of information doctrine has served the interests of western countries, and, in particular, western business interests).

30. C. WeLLS supra note 21 , at 99.

31. Id. at 102.

32. See id. at 102-03. 
Tension continued between the West and the Third World. In 1984, the United States withdrew from UNESCO, based in part on its opposition to the organization's global communications policies. ${ }^{33}$ In the last few years, UNESCO has continued to carry out studies on global commumcations but has proceeded with caution in order to avoid further confrontation with the West and more unfavorable publicity. ${ }^{34}$

II

\section{The THIRd WORLd POSITION ON THE INTERNATIONAL FLOW OF NEWS}

\section{A. The Third World's Dissatisfaction With the Current International News Structure}

Fundamentally, the Third World complains of the extreme imbalance in the flow of news between developed and developing countries. The West controls the international news channels and gives very limited coverage to developments in Third World countries. A leading proponent of the NIIO, Mustapha Masmoudi from Tunisia, argues that close to eighty percent of the world news flow comes from the five major transnational news agencies (TNNAs): Associated Press (AP) and United Press International (UPI) from the United States, Reuters from Great Britain, Agence France-Presse (AFP), and Tass from the Soviet Union. ${ }^{35}$ According to Masmoudi, these agencies devote only twenty to thirty percent of their news coverage to the Third World. ${ }^{36}$

Due to western domination of the international news channels, many Third World countries are forced to depend primarily on the TNNAs for information about the rest of the world. Even those regional

33. See supra note 8 and accompanying text. The timing of the withdrawal was perplexing as even the State Department had admitted that the 1983 UNESCO General Conference had been the most constructive one in a long time. See U.S. WiThDRAWAL, supra note 8, at 52 (letter from Secretary of State Schultz to UNESCO Director General M'Bow).

34. See Jones, supra note 9, at 44, col. 1; C. WELLS, supra note 21, at 111-13.

35. Masmoudi, The New World Information Order, in CRISIS IN INTERNational News, supra note 29, at 79 . Although the Soviet Union possesses Tass, a major international news reporting channel, and is therefore subject to much of the same criticisms as those directed against the United States and other western countries, NIIO advocates have generally restricted their attacks to western nations' domination. The debate has thus been framed as one between the Third World and the West, with the Soviet bloc generally siding with the Third World. This Comment accordingly addresses itself to the charge of western domination of international communications; however, many of its conclusions on the proper U.S. response to the NHO are equally applicable to the Soviet Union. See Righter, World Communication Issues, in Crisis IN INTERNational News, supra note 29, at 60 (listing the five major TNNAs).

36. Id. While some people have cavilled with the exact numbers, see, e.g., M. RosENBLUM, COUPS AND EARTHQUAKES 208-09 (1979) (citing a study indicating that 50\% of the items on the TNNA's world wires at least partially relate to developing countries), there is no indication that the West disputes the Third World's argument that the TNNA's do not provide coverage of developing countries commensurate to their percentage of the world population. 
Third World news agencies that collect the pooled resources of several developing nations are forced to rely on TNNAs for their international news. ${ }^{37}$ Indeed, Biola Olasope, from the Nigerian Broadcasting Corporation, notes that "African mass media organizations are dependent almost exclusively on the Western-owned news agencies for their supply of news about Africa and the rest of the world."38 Similarly, most Latin American countries depend upon UPI and AP for their foreign news. ${ }^{39}$ NIIO advocates complain that because the TNNAs concentrate on the developed world, Third World residents lack access to news on events most relevant to them; specifically, news about other Third World countries whose problems and experiences are most likely to be similar to those facing their own countries. ${ }^{40}$

NIIO advocates also complain that what limited coverage on the Third World does exist is generally negative, incomplete, distorted, and ethnocentric. This follows from the limited familiarity of western journalists with the regions they are covering. Narinder Aggarwala, a leading Third World advocate of the NIIO, argues that the training, upbringing, and value systems of journalists and editors play an important role in deternnining what is news. ${ }^{41}$ Hence, western journalists are prone to evaluate the events in foreign countries through western massmedia values, leading them to focus in on "sensational" events such as coups, general strikes, and street demonstrations and to ignore or overlook stories of particular interest to Third World nations such as progress in economic and health development. ${ }^{42}$ Even where foreign correspondents possess a richer understanding of the area, Aggarwala argues, the dictates of western journalism usually exclude such "thought pieces" from the limited news space available. ${ }^{43}$

NIIO advocates describe a myriad of ways in which western news coverage distorts events and developments in the Third World. One form of distortion consists of focusing on the western angle at the expense of the broader picture. For example, while covering the civil war in Zaire in 1978, western journalists devoted considerable attention to the murder of sixty to sixty-five white Europeans but gave little coverage to

37. A. MEHRA, supra note 7 , at 67 .

38. Olasope, The Nonaligned News Agencies Pool and the Free Flow of Meaningful News: An African Viewpoint, in THE THIRD World AND PRESS Freedom 162, 165 (P. Horton ed. 1978).

39. Beltran \& Fox de Cardona, Latin America and the United States: Flaws in the Free Flow of Information, in NATIONAL SOVEREIGNTY AND INTERNATIONAL COMMUNICATION 33, 39 (K. Nordenstreng \& $\mathrm{H}$. Schiller eds. 1979).

40. D. Mankekar, Whose Freedom? Whose Order? 144-45 (1981).

41. Aggarwala, $A$ Third World View, in Crisis IN INTERnational News, supra note 29, at xix-xx.

42. Aggarwala, News with Third World Perspectives: A Practical Suggestion, in THE THIRD WORLD AND PRESS FREEDOM, supra note 38, at 199.

43. Id. 
the approximately one thousand black Africans that were killed as well. ${ }^{44}$ Another type of distortion is presenting news of Third World countries in light of U.S. and western interests. Examples of this type of distortion include the characterizing of political movements in Third World countries on the basis of their attitude toward the West; those hostile to the West are labeled "extremists" while those friendly to the West are classified as "pragmatically oriented." 45 Other types of distortion include mischaracterization of events by placing them out of context $\mathrm{t}^{46}$ and presentation of events in a way that furthers the foreign policy interests of the western county. ${ }^{47}$

Another complaint of Third World nations is that the mass penetration of western news media harms the cultural and sovereign identity of their countries. ${ }^{48}$ The combination of limited coverage of developing countries and the filtering of all news through western moral, cultural, and political values engenders a feeling of impotence and fosters instability annong Third World people. ${ }^{49}$ Western coverage of developing countries is crisis oriented in nature. Positive developinents in the Third World such as improvements in food distribution or health care are not deemed newsworthy and are thus ignored while ethnic unrest, violence, natural disasters, and technical backwardness are stressed. ${ }^{50}$ In short, by extolling western values, trumpeting the high standard of living in the West (through extensive coverage of events in the prosperous western countries), and denigrating the traditions and values of Third World countries, the media pushes the people in these countries to question their own cultural heritage. ${ }^{51}$

Some NIIO advocates go so far as to accuse the western inedia of deliberately fostering negative, distorted, and ethnocentric coverage of

44. The EdWard R. Murrow Symposium 1979, The INTERnational RightS OF Media NEws Flow 30 (1979) (remarks by Narinder Aggarwala). (1982).

45. G. Hedebro, Communication and Social Change in Developing Nations 57

46. S. MacBride, ManY VoICes, ONE WoRLd $158 \mathrm{n} .1$ (1980) (noting that in covering the Iranian revolution the American news media concentrated on the Islamic fanatics rather than the repressive rule of the Shah and his longstanding U.S. support).

47. D. MANKEKAR, supra note 40 , at $65-67$ (examples cited include scanty coverage of a Pakistani mob's attack of the U.S. embassy in Islamabad in November 1979 because the U.S. government was seeking assistance from President $\mathrm{Zia}$ in aiding the Afghan resistance to the Soviet invasion, biased coverage of the Vietnam War, and overlooking of the Shah's repressive measures).

48. Id. at $122-35$ (referring to communication in general but noting that domination of news reporting is one form of western cultural invasion); S. MACBRIDE, supra note 46, at 160-61.

49. See Masmoudi, supra note 35, at 80-81 (noting that western news coverage of the world is distorted by reference to western values); Ng'weno, All Freedom is at Stake, in THE THIRD WoRLD AND Press Freedom, supra note 38, at 127-28.

50. See D. MANKEKAR, supra note 40 , at $62-65$; see also S. MACBRIDE, supra note 46 , at 160 61; A. MEHRA, supra note 7, at 88-89 (all noting the harmful effects of crisis-oriented journalism on Third World people).

51. See Chin-Chuan Lee, Media Imperialism Reconsidered 100-04 (1980). 
the Third World in order to maintain and increase western econounic superiority and doininance over the Third World. As the late Indira Gandhi once remarked:

The media of the powerful countries want to depict thc governments of their erstwhile colonies as inept and corrupt and yearning for the good old days. This cannot be attributed to the common human failing for nostalgia. To a larger extent there is a deliberate purpose. ... We want to hear Africans on Africa. You should similarly be able to get an Indian explanation of events in India. ${ }^{52}$

Finally, the Third World has claimed that the West uses its domination of the international press to advance its own interests abroad. Altaf Gauhar, from Pakistan, editor of Third World Quarterly, points to a U.S. Senate Select Coinmittee on Intelligence report which states, "[t]he Central Intelligence Agency (CIA) has been engaging acadeınics and journalists for intelligence purposes. Journalist organizations were financed to proinote a "favourable iinage of America." "53 Basskaran Nair describes how U.S. multinational corporations coinbined with the U.S. inedia to attack Salvador Allende, the deinocratically elected socialist President of Chile, in the U.S. media, the international media, and even the Chilean media. In addition to the U.S. media's nearly entirely negative coverage of Allende, ITT and other U.S. Inultinationals in Chile puinped advertising into El Mercurio, an anti-Allende newspaper with the largest circulation in Chile, placed anti-Allende propagandists on Chilean radio and television, and pressured the United States Information Service to disseininate the $E l$ Mercurio editorials throughout Latin Annerica and Europe. $^{54}$ Interestingly, Luis Beltran and Elizabeth Fox de Cardona point out that according to a Senate Staff Report, "The freedoin of the press issue was the single inost important theine in the international propaganda campaign against Allende."s5

52. Speech given at a Non-aligned Nations' conference in New Delhi in 1976, reprinted in A. MEHRA, supra note 7, at 87.

53. Gauhar, Free Flow of Information: Myths and Shibboleths, THIRD WORLD QUARTERLY, July 1979, at 53, 70 n.23 (quoting S. REP. No. 755, 94th Cong., 2d Sess. 192 (1976)). While critical of the current "free flow of information," Gauhar is also highly skeptical of the NIIO. See id. at 59. 60.

54. B. Nair, Mass Media and the Transnational Corporation 56-57 (1980). Similarly, Luis Beltran and Elizabeth Fox de Cardona, Latin American representatives of the International Development Research Centre in Bogota, describe the CIA's use of the media within Chile and the international media to attack the policies of the Allende government. Beltran \& Fox de Cardona, supra note 39, at 44-45.

55. Beltran \& Fox de Cordona, supra note 39, at 45 (quoting from STAFF of SENATE SELECT COMMITTEe TO STUDY GOVERNMENTAL OPERATIONS WITH RESPECT TO INTELlGeNCE Activities, 94th Cong., 1st Sess., Report on Covert ACtion IN Chile, 1963-1973, at 29 (Comm. Print 1975)). 


\section{B. The Third World Solution: The NIIO}

In a resolution adopted at the fourth ineeting of the Inter-Governmental Coordinating Council for Information of Non-aligned Countries in Baghdad in 1980, the Third World sponsors of the NIIO stated that the NIIO is based on:

(a) the fundamental principles of international law, notably self-determination of peoples, sovereign equality of states and non-mterference in internal affairs of other states,

(b) the right of every nation to develop its own independent inforination system and to protect its national sovereignty and cultural identity, in particular by regnlating the activities of the transnational corporations,

(c) the right of people and individuals to acquire an objective picture of reality by means of accurate and comprehensive information as well as to express themselves freely through various inedia of culture and communication,

(d) the right of every nation to use its means of information to make known worldwide its interests, its aspirations and its political, moral and cultural values,

(e) the right of every nation to participate, on the governmental and nongovernmental level, in the intntional [sic] exchange of information under favourable conditions in a sense of equality, justice and inutual advantage,

(f) the responsibility of various actors in the process of information for its trnthfulness and objectivity as well as for the particular social objectives to which the information activities are dedicated. ${ }^{56}$

The NIIO is designed to effectuate a balanced flow of information. In contrast to the western scheine of a free flow of information-which NIIO advocates see as "freedoin of the informing agent" to continue dommating the media ${ }^{57}$ - the NIIO seeks a "world information and communication order 'based on the free circulation and wider and betterbalanced world information and communication order', which reflects 'the concerns and legitimate aspirations of the developing countries." "58

The most inportant proposal in the NIIO is that all developing

56. K. Nordenstreng, The Mass Media Declaration of UNESCO $69-70$ (1984).

57. See Masmoudi, supra note 35 , at 82.

58. A. MEHRA, supra note 7, at 44 (quoting from United Nations General Assembly Resolution 33/115B).

The NIIO has been viewed as part of a larger scheme to help effectuate a more equitable international economic order. Masmoudi has asserted that "the establishment of a new world information order must be considered as the essential corollary of the new international economic order," Masmoudi, supra note 35, at 96. The principal goals of the New International Economic Order (NIEO) "are to close the resource gap" between the developing nations and the developed nations "and to enhance "the capacity of developing countries for self-sustained as contrasted with dependent development.' " Trubek, Economic, Social and Cultural Rights in the Third World: Human Rights Law and Human Needs Programs, in HUMAN Rights IN INT'L LAw: LEGAL AND Policy Issues 205, 247 (T. Meron ed. 1984) (footnote omitted). 
countries formulate and implement a national communications policy. NIIO advocates stress the great role that communication plays in advancing a nation's developmental needs and freeing it from foreign domination. Biola Olasope comments that the decision made at the Non-aligned Nations' meeting in 1976 to set up a nonaligned news agency pool is regarded by some as having set in motion the second phase in the liberation of the peoples of Africa, Asia, and Latin America from colonial domination. ${ }^{59}$ Similarly, the MacBride Commission notes that "information and communication are an essential factor of international relations in all fields and particularly in the establishment of a new system founded on the principle of equality of rights and the independence and unfettered development of countries and peoples."60

Under a national policy, the government would ensure that sufficient resources are devoted to establishing an indigenous news service and would forestall unwanted influence froin transnational corporations. ${ }^{61}$ Although the media would not need to be government-controlled, ${ }^{62}$ the state would encourage the press to give extensive coverage to indigenous concerns. By reporting the news from the perspective of the developing country rather than from the perspective of the TNNA, the indigenous news service would serve two important functions: it would help shape and advance the nation's particular developmental needs, and it would preserve and foster the nation's cultural identity. ${ }^{63}$

A national communications policy for developing nations envisions a development-oriented journalism. The media in these nations would give extensive coverage to development news such as agricultural projects, industrial policy, literacy projects, population control, and emerging political developments in the Third World. ${ }^{64}$ In contrast to the western news media, which concentrates on "events," such as uprisings, elections, and natural disasters, the indigenous Third World media would concentrate on "processes," such as emerging relations between Third World nations, efforts to organize rural health services, the devel-

59. Olasope, supra note 38 , at 162 .

60. S. MACBRIDE, supra note 46 , at 39 .

61. See supra text accompanying note 56: "the right of every nation to develop its own independent information system ... in particular by regulating the activities of the transnational corporations."

62. See infra notes $66-69$ and accompanying text.

63. See G. Hedebro, supra note 45 , at 108-09 (describing the potentially positive effect of an indigenous news media on a country's development); S. MACBR1DE, supra note 46, at 256 (describing communications as an integral part of education and development, providing an opportunity for diversified cultural expression).

64. See Aggarwala, supra note 41, at xix (decrying the western event-foeused coverage and stressing the preferability of news about development). 
opment of inland fisheries, and the introduction of animal traction for farming. ${ }^{65}$

The NIIO does not necessarily advocate a government-owned media. Kaarle Nordenstreng, one of the drafters of the Mexico Declaration, ${ }^{66}$ stresses that "the new order movement has never suggested governmental control as a universal model for the management of the media."67 Indeed, although most NIIO supporters agree that significant government intervention is needed to effectuate the NIIO, some Third World supporters of the NIIO, including Narinder Aggarwala, are opposed to government-controlled news agencies. ${ }^{68}$ The MacBride Commission firmly opposed government licensing of journalists and government involvement in the adoption of a professional code of ethics. ${ }^{69}$

As a corollary to developing independent indigenous news services, the NIIO calls for greater cooperation annong developing countries in gathering and sharing news. Cooperation would involve regional news pools, regular exchanges of news programs, coninon training strategies, the sharing of technological knowledge, mutual assistance in obtaining needed equipinent, exchanges of journalists, and frequent international forunis to discuss relevant trends, problenis, and strategies in coninunication developnient. ${ }^{70}$ Perhaps most importantly, such cooperation involves having the media of individual Third World nations cover developments in neighboring countries and in other less developed nations with similar problems and experiences. ${ }^{71}$

Another NIIO proposal calls for significant financial and technical assistance from the West to establish indigenous conimunication infrastructures in the Third World. ${ }^{72}$ Concerned, in part, that the West will attach restrictive conditions to its aid, Masmoudi and others have called for such assistance to be distributed through international organizations such as UNESCO. ${ }^{73}$ Specific areas in which these international organizations can offer assistance include technology transfers, aid for higher education in comnunications science within Third World countries, tariff reductions for conmunications flowing from developing countries, and

65. See Aggarwala, supra note 42, at 199 (describing Third World need for coverage of these processes).

66. See infra note 80 and accompanying text.

67. K. NORDENSTRENG, supra note 56, at 253 (emphasis in original).

68. See Aggarwala, supra note 42, at 202-03.

69. S. MACBRIDE, supra note 46 , at 262.

70. See Masmoudi, supra note 35 , at $87-88$.

71. See S. MACBRIDE, supra note 46, at 269; see also Anderson, Emerging Patterns of Global News Cooperation, in CRisis IN INTERnATIONAL NEwS, supra note 29, at 318 (describing this extended coverage as one of the "New Order" trends of the 1980s).

72. This proposal is consistent with the redistributive philosophy underlying the NIEO. See supra note 58.

73. Masmoudi, supra note 35 , at 89 . 
research into-and testing of-new, inexpensive, and easy-to-use commurrications technology. ${ }^{74}$

The other major proposals for bringing about a balanced infornation order include having the western media provide mcreased, better inforined, and inore diversified coverage of the Third World, providing the right to reply to and correct maccurate and distorted news stories, and removing western-induced obstacles to the access of various international communications channels. ${ }^{75}$

NIIO advocates have suggested a number of ideas for improving western inedia coverage of the Third World. One idea is to encourage greater western reliance on Third World news agencies for news on developing countries. ${ }^{76}$ Of course, as one NIIO advocate has noted, this necessitates the developinent of inore advanced Third World news agencies capable of providing a variety of Third World perspectives on the news. ${ }^{77}$ Other ideas include exchanging journalists between developing and developed countries, ensuring that western correspondents in developing countries are knowledgeable about the country and the region, encouraging greater awareness in the West of the goals, aspirations, and problems of Third World nations, and encouraging western media to devote inore space, in general, to Third World news. ${ }^{78}$

In order to overcome western-induced obstacles to communications channels, developing countries call for significantly reduced postal rates for newspapers and other publications from the Third World, general reforms in the telecommumication tariff structure to favor transmissions from developing countries, increased Third World access to satellite services, and a nore favorable reallocation of the distribution of radio frequencies. ${ }^{79}$

The inost controversial proposals in the NIIO are those dealing with journalistic standards. Although NIIO advocates have devoted very little hiterature to forinulating a specific code of ethics, they have given considerable attention to what would be the underlying set of principles. At a 1980 meeting in Mexico City of nearly 300,000 journalists worldwideall supporters of the NIIO-the participants agreed on a set of principles to be used as tlie basis for preparing an international code of journalistic

74. Id. at $84-90$.

75. S. MACBRIDE, supra note 46, at 263-66. See Masmoudi, supra note 35, at 91-92.

76. See Aggarwala, supra note 42, at 208 (describing a plan for the development of a credible Third World News Agency that would disseminate news to the West).

77. Id. Aggarwala firmly calls for such news agencies to be completely free from government control.

78. Masmoudi, supra note 35, at 87-89; T. McPhail, Electronic Colonialism 216-17 (1981).

79. Masmoudi, supra note 35, at 84-86. Cf. Abel, Communication for an Interdependent, Pluralistic World, in CRISIS IN INTERNATIONAL NEws, supra note 29, at 106-09 (U.S. opponent of the NIIO who is, interestingly, suggesting similar proposals). 
ethics. ${ }^{80}$ Principle II reflects the NIIO viewpoint that journalistic freedom and responsibility are inseparable:

The foremost task of the journalist is to serve this right to true and authentic information, information understood as social need and not commodity, which means that the journalist shares responsibility for the information transmitted and is thus accountable not only to those controlling the media but ultimately to the public at large, including various social interests. ${ }^{81}$

In addition to Principle II, Masmoudi and others liave stressed the following journalistic principles: conveying objective, accurate, and balanced information; avoiding abusive uses of the right to access to information; being sensitive to the cultures and concerns of all peoples; presenting the viewpoint of all groups with special attention to minorities and disadvantaged groups; and defining appropriate criteria for determining objectivity. ${ }^{82}$ The MacBride Commission has called for international press councils, ombudspersons, and other peer group organizations to oversee journalistic behavior. ${ }^{83}$ Other controversial ideas put forth include licensing journalists and holding individual countries responsible for the behavior of their journalists. ${ }^{84}$

NIIO advocates contrast their view of the journalist's role with what they label the western libertarian view. As noted by one western supporter of the NIIO, the classic western view is that journalists should be value neutral when transmitting facts and opinions so as to ensure objectivity. ${ }^{85}$ In contrast, NIIO advocates argue that the journalist must stand for the values of "peace, democracy, luman rights, social progress and national liberation" and fight against "national, racial, or religious discrimination . . . as well as all forms of colonialism and neo-colonialism." ${ }^{\text {86 }}$ Because they believe that these values should be shared by all peoples, NIIO advocates argue that there should be an international code of journalistic ethics to implement these universal values.

In summary, the NIIO is a response to the developing countries' growing frustration with the extreme imbalance in international informa-

80. K. NoRDENSTRENG, supra note 56 , app. 25 , at 454 . The set of principles agreed to here became known as the Mexico Declaration.

81. Id. at 455; see S. MACBRIDE, supra note 46, at 261.

82. See Masmoudi, supra note 35, at 91-92; see also A. MEHRA, supra note 7, at $45-46$ (listing principles enumerated at the 1980 UNESCO General Conference).

83. S. MACBRIDE, supra note 46 , at 262.

84. K. NoRDENSTRENG, supra note 56 , at 99 , app. 8 , at 305 (taken from Draft Declaration on Fundamental Principles Governing the Use of the Mass Media in Strengthening Peace and International Understanding and in Combatting War Propaganda, Racism and Apartheid, UNESCO Doc. 19C/91 (1976) calling for the states to be responsible for the actions of their journalists); A. MEHRA, supra note 7, at 125 (discussing proposals to license journalists).

85. K. NORDENSTRENG, supra note 56 , at 258 . Nordenstreng rejects the western libertarian view, calling it "value nihilism." Id.

86. Id. app. 25 at 456 (Mexico Declaration). 
tion. In particular, the Third World objects to U:S. and western domination of international news channels and to the TNNAs' limited, distorted, overly negative, and ethnocentric press coverage of developing nations. The NIIO is designed to redress the imbalance in the flow of news and other information between developing and developed countries and to improve the quantity and quality of western news coverage of the Third World.

To achieve these goals, the NIIO calls for developing countries to formulate a national communications policy, develop indigenous news reporting capabilities, cooperate with each other in bringing about a new order, and devise an international standard for journalistic behavior. Developed countries are asked to provide financial and technical assistance to support Third World countries in developing their own news reporting capabilities, to cooperate in reforming the international commumcation structure so as to allow developing countries much greater access to international communication channels, and to improve the quality and quantity of media coverage of the Third World.

\section{III}

\section{THE U.S. RESPONSE TO THE NIIO}

U.S. reaction to the NIIO can be divided into four major groups. Group One consists of NIIO supporters. Group Two consists of those that are sympathetic to the developing countries' complaints, but object to specific NIIO proposals, particularly the international standards for journalistic behavior. Group Three consists of those who oppose the NIIO in general but are willing to offer financial and technical assistance to the developing countries. This was the general position of the Carter administration. It hoped that providing such assistance would dampen the developing countries' demand to adopt the NIIO. Finally, there is the presently prevailing response, Group Four. This group consists of those who reject the NIIO and any accommodation with NIIO supporters. This was the position of the Reagan administration ${ }^{87}$ and of much of the mainstream press.

The views of Group One, the NIIO supporters, are essentially similar to those set forth in Section II of this Comment. Herbert Schiller, a communications professor, is the leading spokesperson for this group. Schiller argues that multinational corporations have used their domination of the media to advance their business interests. ${ }^{88}$ Furthermore, he

87. While, as with many issues, it is unclear what the Bush administration's position is on the NIIO, President Bush has given no indication that he deviates from the position of his predecessor on this issue.

88. Sehiller, Genesis of the Free Flow of Information Principles, in CRISIS IN INTERNATIONAL NEWS, supra note 29 , at 161-83. 
argues that the dominant U.S. corporations adopted the doctrine of an international free flow of information to facilitate their expansion. ${ }^{89}$ Sinilarly, although he does not accuse the large inultinational corporations of inventing the freedom of press doctrine, Schiller argues that they have Inanipulated this doctrine to secure their continuing dommation of the inedia. He concludes that "[o]ur greatest need today inay be to challenge not the enticing doctrines [such as freedoin of the press] but the inisapplication of these desirable principles in the service of corporate and propertied interests." 90

Those in Group Two seek a modus vivendi between the views of the Third World and those of the West. While these people favor a governinent-free press, they agree with the Third World that western inedia coverage of developing countries is very poor and that Third World countries inust develop their own inedia systems. ${ }^{91}$ Accordingly, this group is not opposed to governinent involvement per se, because it recognizes that in inany poor countries, the governinent is the only party capable of inobilizing sufficient techmical, financial, and political resources to develop an indigenous inedia system. Group Two acknowledges that western concepts of a free press are not applicable to inany developing countries; western-style governinent-free press is based on societal conditions not present in inost of the Third World, such as a high literacy rate, a clear societal cominitment to investigative news, sufficient private capital, and commercial advertising. ${ }^{92}$ As Roger Tatarian, a journalisin professor, explains, "To mveigh against government intervention without weighing these factors is tantamount to telling these nations that they inust forego development of national inedia and make do with what they have." 93

Unlike those im Group One, Tatarian and other Group Two supporters refrain from expressing support for the NIIO. They support the western notion of a free press and hope that given nonintrusive encouragement and assistance from the West, developing nations will ultimately support a government-free press. ${ }^{94}$

Group Three does not inerely withhold support for the NIIO; it opposes the NIIO. The group supports technological and financial assistance for cominunication development but views the NIIO as a serious threat to western free press values. Unlike those in Group Two,

89. Id. at $167-68$.

90. A. MenRA, supra note 7, at 130-31 (quoting Schiller, Information: America's New Global Empire, Channels, Sept.-Oct. 1982, at 30-33).

91. See Tatarian, News Flow in the Third World: An Overview, in The THIRD WorLd AND PRESS FREedom, supra note 38 , at 36-47.

92. Id. at $43,46-47$.

93. Id. at 47.

94. Id. at $47-48$. 
these people are very critical of the idea of a government-run press in any society and are much more worried about the impact of the NIIO on developing countries' treatment of American journalists. This group recognizes, however, that the Third World nations have a legitimate grievance which may attract substantial sympathy in the international commumity. They understand that the United States risks losing considerable stature in the international coinmunity if it simply ignores or rejects the developing countries' complaints on the inedia imbalance. Hence, while denying that the imbalance is the result of some conscious deliberation of western commercial interests, this group stresses focusing on areas of potential agreement. ${ }^{95}$

Kaarle Nordenstreng has labeled this compromise position as the "flexible liberal" response. ${ }^{96}$ This position reflected President Carter's goal to "cooperate more closely with the newly influential countries in Latin America, Africa and Asia [and engage] their friendship and cooperation in a common effort as the structure of world power changes." 97 Consistent with this approach to foreign policy, Group Three recominends that the U.S. and other western governments implement practical programs for improving the mass inedia infrastructure of the developing countries im the hope that these countries will drop their demands for fundamental changes in the international system. ${ }^{98}$ One report to the U.S. Senate phrased the goal as:

Worldwide the "New World Information Order" could be good or bad.

As the situation now stands, the U.S. has more to lose than any other nation as the "Order" becomes a fact. It should be noted, however, that the U.S. need not be a loser if appropriate actions are taken. ${ }^{99}$

Elie Abel, the American representative on the MacBride Commission, ${ }^{100}$ articulates specific areas in which developing countries and developed countries can cooperate to reduce the imbalance. Many of them are similar to the suggestions made by NIIO advocates. ${ }^{101}$ How-

95. See, e.g., Abel, supra note 79, at 97-116 (advocating a search for consensus among nations on communication values and journalistic ethics rather than the imposition of a global standard).

96. K. NORDENSTRENG, supra note 56, at 59.

97. Carter, Address at Commencement Exercises at the University, University of Notre Dame, 22 May 1977, in Series: Public PAPers of the Presidents Vol. Jimmy Carter I (1977) 961.

98. See K. Nordenstreng, supra note 56, at 17 (discussing THE NEW WORLD INFORMATION ORDER, A Report by George Kroloff and Scott Cohen to the Committee on Foreign Relations, United States Senate, November 1977 [hereinafter THE KROLOFF \& CoHEN REPORT]); see also Righter, World Communication 1ssues, in CRISIS IN INTERNATIONAL NEWS, supra note 29, at 75 (West should concentrate on improving Third World communication systems and hope that they will disseminate news rather than propaganda).

99. K. Nordenstreng, supra note 56, at 17 (quoting The Kroloff \& CoHeN Report, supra note 98, at 1).

100. See supra note 28 and accompanying text.

101. See supra note 79 and accompanying text. These include reducing the postal rates for newspapers and periodicals from Third World countries, revising the current telecommunication 
ever, instead of coinpelling corrections or retractions whenever foreign governments, or their citizens, claim that a news report is false or distorted, Abel favors encouraging greater use of existing U.S. and western avenues for redressing complaints. These include letters-to-the-editor sections, op-ed pages that feature a diversity of opinions, and press councils that investigate and report public complaints of false or distorted news coverage. ${ }^{102}$ None of these measures would be compelled by governments or established as international law.

Finally, Group Four, which was embodied by the Reagan admimistration and includes much of the inainstream media, rejects the NIIO and any accommodation with the Third World on this issue. They advocate ending U.S. assistance to UNESCO and other multilateral institutions, providing aid to the media systems of all developing countries, and directing U.S. aid to worthy private media efforts in developing countries. ${ }^{103}$ They view the Carter administration's "flexible liberal" response as a failure in that it did not deter the Third World from pursumg an antiwestern ideological agenda. Colummist Charles Krauthammer of The New Republic exemplifies this view:

What is the point of this [Group Three] approach? What do we gain by fighting to contain the anti-free-press forces? There is no hope of bringing the Soviets or the third world to accept Western views on the free press. The price of this battle has been a continuing series of compromises. ${ }^{104}$

\section{A. Western Criticism of the Third World Diagnosis of the Problem}

Every Group, except Group One, has disputed specific charges raised by the developing countries against the western media. First, they argue that the limited and often negative and distorted coverage of the Third World does not reflect a conscious motive on the part of western commercial interests to maintain their domination in the Third World.

tariff structure to create preferential rates for transmissions from developing countries, offering universal access to satellite services, and having the West offer financial, technical, and training assistance. Abel, supra note 79, at 106-10.

102. Abel, supra note 79, at 113-14.

103. See, e.g., U.S. WITHDRAWAL, supra note 8, at 96 ("[Our withdrawal from UNESCO] would allow us to be more selective in directing any future support we might offer to the private media in developing countries. We could, for example, continue to support worthy IPDC [International Programme for Development of Communication] projects bilaterally, and we could increase our contributions to private American institutions offering communications development assistance.").

104. Krauthammer, Brave News World, The New Republic, Mar. 14, 1981, at 21, 23. Presciently, Krauthammer concluded in his article that if the Third World nations continue to pursue the NIIO agenda in UNESCO, the United States should withdraw from UNESCO. Id. On December 29, 1983, the Reagan Administration announced its intention to withdraw from UNESCO; giving as one of its reasons UNESCO's continued championing of the NIIO. U.S. WITHDRAWAL, supra note 8, at 6, 31-32 (Appendix 4). 
Roger Tatarian points out that the TNNAs, unlike profit-making multinational corporations such as IBM or Unilever, do not operate in search of profits but in search of news. ${ }^{105}$ In fact, Tatarian notes that the TNNAs ran up a large deficit in Vietnam during the war there and have made very little money in Israel. ${ }^{106}$ Most western commentators have cited the following reasons for the poor quality of western media coverage of the Third World:

(1) The high cost costs of maintaining correspondents in foreign countries. ${ }^{107}$

(2) Undue government restrictions on journalists, such as censorship, restricted access, detainment, and threats of physical abuse. ${ }^{108}$

(3) The lack of public interest in the West in in-depth pieces on development issues such as population, education, health care, and agricultural projects. ${ }^{109}$

(4) The nature of the mass media which prefers simplified stories, ${ }^{110}$ negative events, and hyped up stories. ${ }^{111}$

Many westerners argue that imbalances in news coverage are inevitable "because the ruling principle in journalism is not distributive justice but newsworthiness."112 The media naturally covers the powerful because their actions are most likely to affect the rest of the world. Developments in the Soviet Union or in Western Europe are more likely to have an impact beyond their borders than events in Trinidad; accordingly, the media directs its coverage to the former. One defender of this practice argues that the media in most Third World nations also concentrates its coverage on the West and the Soviet Union over developments in other Third World nations. ${ }^{113}$ Western commentators also point to the newsworthiness principle to explain why news stories are disproportionately negative. Drummond argues that news reporting consists of "highlighting the exceptional-the plane that crashes, not the one that lands, the country that defaults on its bank loans, not the country that makes the payments on time."114 This ruling principle applies with equal force to news coverage in the Third World and in the West.

Some respondents have argued that NIIO advocates exaggerate the

105. Tatarian, supra note 91 , at 33.

106. Id.

107. T. MCPhAlL, supra note 78, at 16-17; Tatarian, supra note 91 , at 33 .

108. T. MCPhaIL, supra note 78 , at 16-17.

109. Id.

110. M. RosenBluM, supra note 36 , at $4-5$.

111. Drummond, Third World News Coverage: A Change in the Prestige Press 2 (prepared for the Western Communication Educators Conference, Nov. 14, 1987) (on file with the Califormia Law Review).

112. Krauthammer, supra note 104 , at 22 .

113. Merrili, A Growing Controversy: The "Free Flow" of News Among Nations, in CRISIS IN INTERNATIONAL NEwS, supra note 29, at 159.

114. Drummond, supra note 111 , at 2 . 
degree to which western media coverage of the Third World is limited, negative, and distorted. Mort Rosenblum cites to a University of Hong Kong study in 1977 that found that more than fifty percent of the itens on the world wires of the four inajor news agencies at least partially concerned developing countries. ${ }^{115}$ Less than six percent of these stories dealt with violence, disaster, or conflict. Charles Krauthammer points to a study that Phil Harris of InterPress Service (IPS) conducted for UNESCO. According to Krauthammer, Harris reviewed news reports sent out by Reuters, AFP, and UPI "and concluded that they did not portray the third world as a place of endemic tragedy and disaster."116

Furthermore, some argue that press coverage of the Third World has considerably improved over the past decade. Rosenblum notes that many western editors have been sensitized to the concerns of Third World countries and encourage their reporters in developing countries to take a more balanced approach. ${ }^{117}$ Journalisin professor William Drummond argues that the "prestige press" of America-The New York Times, The Wall Street Journal, and the Christian Science Monitor-has noticeably improved both the depth and breadth of its coverage of the Third World. One reason for this improveinent, according to Drummond, is a growing awareness that developments and events in the Third World-such as the Arab oil boycott, the chaos in Iran (and the ensuing war in the Persian Gulf), and the huge Third World debt-greatly affect the United States. ${ }^{118}$

Finally, westerners object to the charge that Third World countries are forced to receive news on the rest of the world from ethnocentric western agencies. ${ }^{119}$ Elie Abel notes that in most developing countries, it is the governinent or government-controlled agency that subscribes to TNNA services. ${ }^{120}$ If the government does not like a news report, it can either revise the story or simply refuse to run it. Hence, Abel concludes that "the picture of passive millions in the developing countries awash in a tidal wave of alien information is somewhat fanciful."121

115. M. RosenBluM, supra note 36 , at 208-09.

116. Krauthammer, supra note 104 , at 22 . However, Krauthammer neglected to mention that Phil Harris concluded that his empirical studies supported most of the Third World critique, in particular the fact that the western news agencies "portray an imbalanced image of the role of the Third World in the international arena." Harris, News Dependence and Structural Change, in CRISIS IN INTERNATIONAL NEWS, supra note 29 , at 358.

117. M. Rosenblum, supra note 36 , at 13 .

118. Drummond, supra note 111, at 17-18.

119. See Abel, supra note 79, at 100-01.

120. Id.

121. Id. 


\section{B. Western Criticism of the Prescription: The NIIO}

Groups Three and Four have concentrated their attack on three general proposals in the NIIO: (1) enlisting the mass media in the process of development; (2) providing Third World nations increased access to the media, including the right to reply, and the right to correction; and (3) regulation of the international news media.

Leonard Sussman, executive director of Freedom House, ${ }^{122}$ has derided the NIIO advocacy of "development journalism"-using the media to advance development-as a concept created by the Third World to justify complete government control over the press. ${ }^{123}$ Because many Third World nations favor heavy governmental involvement in the nation's development, Sussman argues that actively enlisting journalism in development efforts will result in the media becoming another government tool.

Groups Three and Four also disfavor NIIO proposals for greater Third World access to the western news agencies, both through greater western reliance on Third World news agencies, and by granting Third World individuals and governments the right to correct or rebut western reports. ${ }^{124}$ Groups Three and Four object to the first of these proposals because many of the Third World news agencies are government-controlled and thus cannot be trusted to give accurate news accounts. ${ }^{125}$ The problem with the automatic right of reply and correction is the obvious fear of abuse. Rather than "replying" to and "correcting" inaccurate or distorted news stories, many of the authoritarian governments may simply "correct" stories that are unfavorable to them. ${ }^{126}$

The third group of NIIO proposals to which the West strongly objects are those advocating, explicitly or implicitly, increased governmental or international control over journalists. These include calls for an internationally defined code of behavior, the creation of international

122. Freedom House is a U.S. monitor of political rights and civil liberties across the world that strongly opposes the NIIO.

123. Sussman, Mass News Media and the Third World Challenge, in INTERNATIONAL News: Freedom UNDER ATTACK 105, 139 (D. Fascell ed. 1979).

124. See supra notes $75-77$ and accompanying text.

125. Sussman, supra note 123, at 164 . Of course, as Sussman points out, western news agencies will find these government reports helpful, but will need to investigate the situation themselves rather than merely print the government report. Id.; but $c f$. Rosenblum, The Western Wire Services and the Third World, in The THIRD WorLd AND PRESS FReEdoM, supra note 38, at 111 (noting that "dispatches from government news agencies can sometimes present a more balanced picture of local developments than those of the independent global agencies.").

Media critic Ben Bagdikian, however, argues that the mainstream press is quick to accept official sources of information for its domestic coverage. B. BAGDIKIAN, THE MEDIA MONOPOLY 179-81 (2d ed. 1987).

126. Presumably, western news agencies and newspapers will be able to makc it clear that the correction or reply is at the behest of the government but this right will arguably allow for unwarranted attacks on the newspaper's integrity and independence. 
press councils to oversee journalistic behavior, government licensing of journalists, and proposals sanctioning increased government regulation of incoming and outgoing news. ${ }^{127}$ Elie Abel asks:

Who would define "abusive uses" of the right of access? Who would determine the "appropriate criteria" for "truly objective" news selection? Who would regulate the flow of news across national frontiers? Does not each of these proposed measures imvite official interference with the flow of information? Is [this] not, in effect proposing an elaborate new system of censorship? ${ }^{28}$

In short, the West objects to these proposals because it believes it is unworkable to come up with a single code of behavior to govern the multitude of news systems in the world and, more importantly, such proposals intrude on the independence of the press by subjecting it to the influence, if not control, of governments inore interested in good public relations than in the truth. ${ }^{129}$

\section{IV}

\section{A Proper U.S. ApProach to the NIIO}

Notwithstanding U.S. and western opposition to the NIIO, no country could dispute that the press can play either a constructive or destructive role in a country's development. Similarly, the United States and the West would likely concede, im principle, that the massive western media penetration into developing countries can distort the cultural identity of these nations. As set forth in Section II, developing countries maintain, with much justification, that the West's invocation of freedom of the press perpetuates a media hegemony that hinders them from attaining viable political and economic systems and preserving their cultural identities. Developing countries assert that their very sovereignty and independence are at stake. They are therefore prepared to wage a long-term battle for control over the news media. This part proposes a viable framework from which the United States can respond to and accommodate these Third World concerns.

\section{A. U.S. Concern Should Be to Advance the Economic, Political, and Cultural Welfare of the Third World}

The current U.S. preoccupation with value-laden labels such as "free flow of information" and "freedom of the press" has obscured important Third World concerns. This section argues that U.S. policy should concentrate on whether and to what degree the NIIO advances the economic, social, and cultural position of the developing countries.

127. See supra notes 80-84 and accompanying text.

128. Abel, supra note 79 , at 111 .

129. Id. at 112 . 
This approach would focus on economic advancement, political stability, popular support for the government, cultural integrity, and the protection of generally accepted fundamental human rights. ${ }^{130}$

A progressive needs-based policy can be justified on both pragmatic and moral grounds. Pragmatically, the United States will win more friends in the long run by giving priority to the political, economic, and cultural needs of the developing countries over its own short-term military-economic interests. In evaluating the NIIO, the United States may wish to consider the disastrous consequences of failing to respect the long-term concerns of developing nations. Iran offers a dramatic example. Every American administration beginning with President Eisenhower strongly backed the Shah despite the fact that his reign grew increasingly repressive. ${ }^{131}$ The United States did so because "Iran [was] not just a major oil supplier. It ha[d] also been the major local protector of western interests."132 The United States made no real attempt to improve the Shah's oppressive rule. ${ }^{133}$ Not surprisingly, the Iranians became virulently anti-American and, following a violent coup, placed their support in the Ayatollah Khomeini who espoused a policy of anger and violence against the United States.

Similarly, in Nicaragua, the United States provided longstanding support to the oppressive Somoza regime because of that government's support of U.S. economic interests. ${ }^{134}$ While the Carter Administration did finally withdraw U.S. support for Somoza, it came too late to forestall the suspicion and enmity of most of the Nicaraguan people toward the U.S. government. Many assumed with much justification that the United States was continuing to manipulate the situation to further its own strategic interests. ${ }^{135}$ Furthermore, any chance for improving the U.S. image ended with the U.S.'s quick and hostile reaction to the Sandinista government. Interestingly, even a number of Contra leaders such as Eden Pastora and Arturo Cruz have left the U.S.-backed opposition, noting that the United States is more interested in protecting its

130. This is consistent with David Trubek's view that the United States should subscribe to a progressive international principle whereby the prosperous developed countries have an obligation to assist the less developed countries. Trubek, supra note 58, at 216-17.

131. J. BiLl, The Eagle and the Lion: The Tragedy of AMerican-Iranian Relations 183-215 (1988) (analyzing U.S. relations with Iran from 1941-79 and noting that the Shah's rule grew increasingly repressive in the 1970s).

132. Gauhar, supra note 53, at 62 (quoting All Fall Down, THE Economist, December 16, 1978, at 9).

133. See generally J. BILL, supra note 131.

134. See K. Berman, Under the Big Stick: Nicaragua and the United States Since 1848 219-74 (1986).

135. Id. at 264-74. Even such prominent Nicaraguan conservatives as Archbishop Obando y Bravo complained of the Carter Administration's "continu[ing] to think of their own political interests before the common good of the Nicaraguan people." Id. at 273 (footnote omitted). 
own interests than in advancing democracy in Nicaragua. ${ }^{136}$

Morally, the United States has an obhgation to help those who have suffered from its efforts to manipulate the international order. In particular, the United States should redress having used its domination of cominumications to disseminate propaganda agamst Third World governments in its efforts to advance U.S. interests. For example, in Chile, the United States used its control of international news channels and even of Chilean news channels to attack Allende's government. ${ }^{137}$ The reverse, of course, was not true. The Allende Government did not have control over international or U.S. media outlets through which it could criticize U.S. pohicies or defend itself from various U.S. attacks on government actions. Actively assisting the development of Third World nations may be viewed as compensation or remedial action for earher U.S. action that inay have stunted their developnient.

In adopting a progressive needs-based approach, the United States need not accept the entire NIIO agenda. It should be sensitive to the actual conditions of developing countries and cautious in accepting the claims of foreign leaders. It nuay be that some Third World governments would use the NIIO as simply a vehicle for covering up failure and repression in their countries. Altaf Gauhar, former Secretary of Pakistan's Mimistry of Information \& Broadcasting, sarcastically comments on the Third World demand for much inore positive coverage of authoritarian Third World countries: "How nice to know that their wicked king is, in fact, a reformer and their tyrant, in truth, a moderniser." 138 Nevertheless, such concerns do not justify iguoring Third World complaints about western inedia influence; they mean only that these complaints should be evaluated thoughtfully.

Based on these principles, the Umited States should support the parts of the NIIO that, in conjunction with the NIEO, work toward decreasing the econoumic disparity between developed and developing nations and toward euhancing "the capacity of developing countries for self-sustained as contrasted with dependent development."139 Such a policy, while hardly startling in theory, would be a significant departure from current U.S. pohicy. Foreign aid programs are now primarily based on short-term strategic concerns. ${ }^{140}$ Israel and Egypt together receive nearly half of all foreign aid because they are counted upon to protect

136. See Avirgan \& Honey, The CIA's War in Costa Rica, 244 The Nation 105 (1987) (describing Pastora's falling out with the CIA and the Contras); Lane, Pack it in: Contras, II; American Central American Strategy, THE New Republic, April 6, 1987, at 17 (describing Cruz' falling out with the Contras and his denouncing their leaders as antidemocratic).

137. See supra notes 54-55 and accompanying text.

138. Gauhar, supra note 53 , at 71.

139. Trubek, supra note 58, at 247.

140. See Madison, Overhauling Foreign Aid, 20 NAT'L J. 1410 (1988) (noting that U.S. foreign 
important U.S. interests in the Middle East. ${ }^{141}$ Similarly, Pakistan, another large recipient of U.S. aid, has provided valuable logistical assistance in aiding the Afghan resistance. ${ }^{142}$ While it is perhaps unrealistic to expect the United States to abandon its emphasis on U.S. short-term strategic interests, the country can, at least, broaden its perspective by supporting those parts of the NIIO that contribute to furthering the development of less developed countries.

\section{B. The Reducing of "Freedom of the Press" to a Talismanic Slogan}

Just as the American media has been ethnocentric in its news coverage of the Third World, so too have American policy makers been ethnocentric in their invocation of "freedom of the press." Americans have assumed that freedom of the press requires a private press similar to that in the United States. ${ }^{143}$ Because the NIIO envisions a differently structured press-one not completely isolated from government involvement-American policy makers have derided the proposal as being antifree press.

The American free-market press, however, is not the only way of attaining a free press. Rather, the U.S. press structure is a particular configuration of a free press system, one that developed in response to events, developments, and concerns peculiar to American history. ${ }^{144} \mathrm{~A}$ private press reflects the economic structure of the United States where, unlike developing countries, there has long existed a private sector with significant resources availab.s to operate a press without government help. Indeed, government has historically been viewed as the greatest threat to liberty. In the United States, freedom of the press "was designed to serve as a powerful antidote to any abuses of power by governinental officials." 145 Hence, freedoin of the press became viewed as a press owned by private parties, free of government interference, and critical of the government.

American opponents of the NIIO have for the most part rejected the argument that the U.S. configuration of freedom of the press rests on developments peculiar to American history. Rather, they assert that to be "free," the press must be free from government involvement. This

aid has overemphasized military and economic aid to strategic allies at the expense of aid to poor countries).

141. Id.

142. Id.

143. See, e.g., Lewis, Mr. Murdoch's Shadow, N.Y. Times, Nov. 5, 1987, at A35, col. 5 ("By freedom of the press we mean a privately-owned press free of government interference.").

144. See Hutchinson \& Monahan, The "Rights" Stuff: Roberto Unger and Beyond, 62 TEx. L. REV. 1477, 1490 (1984) ("To assert in principle the value of rights is not to argue for any configuration of rights. Rights have no necessary or inevitable form.").

145. Mills v. Alabama, 384 U.S. 214, 219 (1966). 
type of freedom, they argue, is a necessity for all countries, especially developing countries as only then can a "shaky young statehood ... develop into a strong and secure state, capable of protecting the rights of its citizens." 146

This fixation on a private-press model has proved harmful. "Freedom of the press" has been reduced to a talismamic phrase whereby Americans have fixated on the American model and have overlooked the underlymg values of a free press. ${ }^{147}$ Rather than discussing what values and functions a free press serves, American policy makers have narrowed the focus to mquiring whether a given country's press meets the American private-press model. Where it does not, they conclude that the press is not free. The madequacy of such a test has been clearly demonstrated by recent U.S. policy in Central America. The United States lias assailed the Nicaragnan press as being government-controlled, ${ }^{148}$ while ignoring the status of the privately-owned press in the neighboring countries of Honduras, El Salvador, and Guatemala. In fact, however, the Nicaraguan press presents news from a broader range of ideological perspectives than any of its neighboring countries and is the only country in that region with a siguificant press presence highly critical of the government. ${ }^{149}$

Most of the inainstream mass media have ignored these distinctions and underlying conditions. Instead, they have framed the international debate as a protest against the NIIO's perceived threat to freedom of the press. ${ }^{150}$ Consequently, most Americans that read about this

146. Chancellor, Foreword to Third World AND Press Freedom, supra note 38, at vii (Chancellor believes that no government-run press will allow its journalists to operate freely); see also Sussman, supra note 123, at 171-72 (arguing that the American version of a free press-that is, a private press-reflects an inalienable right applicable to all countries).

147. See Tushnet, An Essay on Rights, 62 TEx. L. REv. 1363, 1383 (1984) (Legal rights discourse in the United States tends to obscure the underlying values and "real experiences on which the language of rights rests but from which it improperly generalizes.").

148. The Reagan Administration and other supporters of aid to the Contras repeatedly listed the lack of a free press in Nicaragua as one basis for supporting opposition to the Sandinista Government. See, e.g., Reagan's Speech to U.N. Assembly: A Call for an End to Regional Clashes, N.Y. Times, Sept. 22, 1987, at 14, col. 1 (expressing continued dissatisfaction with the Sandinista government and exhorting it to establish a "truly free" press); Antevil, Reuters North European Service (Apr. 12, 1983) (In a news conference discussing whether the Reagan Administration was violating a Congressional ban on U.S. aid to the Contras, Secretary of State George Schultz defended the Reagan administration's hostility to the Sandinistas by noting among other things that the government had suppressed freedom of the press).

149. Aryeh Neier, a vice chairman of the Helsinki Watch Committee and of Americas Watch Committee recently concluded that the Nicaraguan press presents news from a broader range of ideological perspectives than El Salvador, Honduras, Guatemala, and Costa Rica. Neier, Has Arias Made a Difference, N.Y. REv. of Books, Mar. 17, 1988, at 22. See also Kinzer, The Mood in Managua, N.Y. Times, Feb. 3, 1988, at A1, col. 3, A10, col. 3 ("No other country in the region boasts a major daily newspaper that fundamentally questions the legitimacy and ideological foundation of the ruling group.").

150. See Hemisphere Court Backs Free Press, N.Y. Times, Nov. 29, 1985, at 19, col. 1 (in 
international debate in the newspapers and newsmagazines are not likely to consider the underlying economic, political, and social issues. Rather, the whole issue is just reduced to another example of "U.S. bashing" in the U.N.

To remedy the damaging effects of this ethnocentrism, it is necessary to move past the label "freedom of the press" and to parse the underlying values of a free press. Then, we can consider whether the American private-press model is a necessary or even effective means of advancing these values in the Third World.

\section{The Underlying Values of a Free Press}

A free press serves three values. First, it fosters an informed citizenry by allowing all viewpoints to be heard. Second, a free press monitors whether the society is being run fairly and effectively. Third, a free press provides an important forum for people to express themselves on public issues, to offer comments, suggestions, or criticisms. ${ }^{151}$

Under the first value, a free press disseminates information without restriction or censorship and thereby informs citizens of all relevant events, developments, and opinions. ${ }^{152}$ This is desirable because an informed citizen is better able to make political, economic, and social decisions that benefit the society as a whole.

A free press serves its second value as a "watchdog" by reporting on the government and other institutions of power in the society. As stated in Mills v. Alabama, "the press serves and was designed to serve as a powerful antidote to any abuses of power by government officials and as a constitutionally chosen means for keeping officials elected by the people responsible to all the people whom they were selected to serve."153

The most important value, the forum for public expression is necessary to effectuate fully the right to freedom of expression. Free expres-

reporting on a holding of the InterAmerican Court of Human Rights, the article reduced UNESCO's advocacy of a NIIO to that of providing a forum for groups desiring licensing of journalists); see also Tuchman, UNESCO Is No Guide, N.Y. Times, Jan. 22, 1984, § 4, at E23.

151. A U.S. State Department consultant has defined the role of a free press in the following manner:

First, it acts as a major source of information, so that people are provided the raw material from which to form opinions and make choices from a wide variety of viewpoints. Second, an unshackled press serves as a monitor, scrutinizing the activities of government and reporting how authority is exercised. Third, a free press serves as a liaison between the state and its citizens. It serves the latter as a sounding board, permitting them openly to voice criticism and complaints as well as suggestions. Through the free press government is continually informed of the people's opinion of its performance.

American Society of International Law, Proceedings of the 73rd Annual Meeting 184 (April 26-28, 1979) reprinted in A. MEHRA, supra note 7, at 13.

152. See A. Melklejohn, Political Freedom: The Constitutional Powers of the PEOPLE 24-28 (1948).

153. 384 U.S. 214,219 (1966). 
sion is desirable because "the final end of the State [is] to make men free to develop their faculties; . . . the greatest menace to freedom is an inert people; ... it is hazardous to discourage thought, hope and imagination."154 This is a compelling value as it rests on the strong natural desire of people to express themselves to the community and on historical experience demonstrating that suppression of speech results in damaging effects. We have ample evidence of the harms suffered by people living in societies not allowing free expression. ${ }^{155}$ Indeed, we do not even have to look outside our own society as the McCarthy era demonstrates the debilitating effects of suppressing dissent. ${ }^{156}$

A free press is necessary because it serves as a public forum for expression. It may be emotionally cathartic to sound off in private but our desire is to be heard, meaning we want the freedom to communicate our thoughts and opinion to others. The media of course is not the only forum for speaking out - other such forums include places of public gathering and the workplace-but it is the most important forum. The media commands the largest audience and unlike other forums, its defining characteristic is communication.

All three of these values have universal merit that should be recognized in all social orders. India's experience under Indira Gandhi's period of emergency rule provides good proof that people in the Third World desire a free press. George Verghese, former editor of the Hindustan Times, writes of the press censorship in India under Indira Gandhi that started in June of 1975 and lasted for twenty months. ${ }^{157}$ Prompted by growing press criticism of widespread government corruption in India and favorable press coverage of antigovernment movements, Gandhi declared a state of emergency that included formal censorship of the press. ${ }^{158}$ The governnent guidelines stated that censorship was " "to ensure that no news is published in a manner that contributes to denioralization about the general situation or the public interest in all respects as determimed by the central governnient." "159 Gandhi greatly underestimated the backlash press control would create with the Indian people. Ending press censorship becanie a major issue in the election of 1977, leading to the only national defeat of Gandhi's Party of Congress.

154. Whitney v. California, 274 U.S. 357, 375 (1927) (Brandeis, J., concurring).

155. See Press Control Around the World 149-234 (J. Curry \& J. Dassin eds. 1982) (chapters on press censorship in Brazil, Egypt, and Sub-Saharan Africa); Drakulic, $A$ Chat With My Censor, 246 THE NATION 336 (1988) (a Yugoslavian journalist's view on the subtle intimidation of the government censor).

156. See generally F. Cook, The Nightmare DeCade (1971); T. Reeves, The Life and TIMES OF JOE MCCARTHY (1982).

157. Verghese, Press Censorship Under Indira Gandhi, in The Third Wordd and Press FREEDOM, supra note 38, at 220.

158. Id. at 221-22.

159. Id. at 222 (quoting the Gandhi government's official censorship guidelines). 


\section{How Helpful is the American Model to Advancing the Underlying Values?}

Current U.S. pohcy assumes that no structure other than a freemarket press can accomplish the values associated with a free press. In fact, however, careful analysis of the media in the United States and in developing countries with a private-market press suggests that the American press model may not even be particularly conducive to furthering free press values in the United States, much less in developing countries.

\section{a. Has the American Press Model Even Served Free Press Values in the United States?}

There are serious threats to a free press in the United States and they emanate not from government but from private corporations. In the United States, the free-market structure of the press has resulted in a growing concentration in media ownership. Ben Bagdikian has determined that twenty-nine corporations control over half of the media in the United States. ${ }^{160}$ Fifteen corporations control half the daily newspaper business; six control more than half of the revenues from magazine sales and advertisement; three corporations control most of the audience in television. ${ }^{161}$

Such concentration hardly serves the value of an informed citizenry receiving a variety of viewpoints. Concentration of ownership means fewer media voices as the interests of the owner are likely to influence the content of the voices being expressed. ${ }^{162}$ In addition, the commodity nature of a private press results in large classes of people being ignored in the news. The large news outlets are dependent upon advertising for most of their revenue. ${ }^{163}$ Advertisers seek to reach affluent customers (middle class or above), between the ages of eighteen and forty-nine. ${ }^{164}$ Consequently, news concerning-or of interest to-groups not meeting this category such as minorities, blue-collar workers, and those with sub-

160. B. BAGDIK1AN, supra note 125 , at 20 . By media, Bagdikian is referring to daily newspapers, magazines, television stations, book publishers, and movie studios. According to a recent review of the book, the number is down to 26. Pollak, supra note 3, at 209. With the recent merger of Time Inc. and Warner Communications, the number may now be 25. Fabrikant, TimeWarner Merger Raises Concerns on Power of a Giant, N.Y. Times, Mar. 6, 1989, at A1, col. 2 (reporting on the merger).

161. B. BAGDIK1AN, supra note 125, at 20.

162. See, e.g., id. at 100-01 (every newspaper owned by the newspaper chains of Hearst, Cox, and Scripps-Howard endorsed President Nixon for reelection in 1972).

163. Id. at 134-51 (describing the huge impact of advertising, noting in particular that in 1980, daily newspapers devoted an average of $65 \%$ of their space to advertising).

164. Id. at 109 . 
middle class incoines may be left out as it does not suit the needs of the advertisers. ${ }^{165}$

Indeed, equating a privately owned press with freedom of the press has coinpounded the problem of media concentration. In the United States, freedom of the press has often been invoked by media conglomerates to forestall government antitrust measures against inedia ownership concentration. ${ }^{166}$ Although U.S. courts have sanctioned some government regulation over control of the radio, ${ }^{167}$ they have held that freedoin of the press prohibits the government from regulating newspapers. ${ }^{168}$

Congresspersons and other interested parties seeking to control press ownership concentration have faced a formidable intellectual and jurisprudential obstacle. No one wants to be seen as anti-free press. Newspaper owners, editors, and columnists often display much skill in denouncing advocates of press ownership regulation as opponents of press freedom. Recently, media magnate Rupert Murdoch decried the Senate's action that ended the Federal Communication Commission's (FCC's) exemption of Murdoch from the media cross-ownership rule. ${ }^{169}$ Murdoch's defenders, imcluding his own newspapers, accused the Senate of removing a dissenting voice in the press. ${ }^{170}$ In reality, the Senate was acting to reinove undue local media concentration.

The free-market's tendency here toward press concentration also impedes the "watchdog" value of the press by inhibiting it from nomitoring corporate actions. Power and authority do not emanate solely from the government. The business community also exercises considerable

165. See id. at 105-33 (advertisers are at least as concerned with the wealth of the audience as with the size).

166. Sometimes these media conglomerates have been more blunt in forestalling antitrust measures against the press. During President Nixon's first administration, Richard Berlin, president and chief executive officer of the Hearst Corporation, successfully lobbied the Nixon administration to support a bill exempting newspapers from certain antitrust laws. Berlin made it clear that a quid pro quo was expected whereby Nixon would support the exemption in exchange for Hearst's newspapers supporting Nixon's reelection. Id. at 90-98.

167. Red Lion Broadeasting Co v. FCC, 395 U.S. 367 (1969) (upholding governmental regulation in the form of the FCC "fairness" doctrine).

168. Miami Herald Publishing Co. v. Tornillo, 418 U.S. 241 (1974) (state prohibited from regulating newspaper content).

169. The cross-ownership rule forbids the same party from holding both a daily newspaper and a radio or TV station in the same community. Murdoch got an exemption from the FCC permitting him to own WNYW-TV and the New York Post in New York City and WFXT-TV and the Boston Herald in Boston. See Simon \& Wagenhauser, Can Rupert Murdoch Have It All?, 246 THE NATION 181 (1988). Murdoch successfully challenged the Senate's provision in court. The circuit court held that the Senate's action focused solely on Murdoch and thus violated his first and fifth amendment rights. News America Pub., Inc. v. F.C.C., 844 F.2d 800 (D.C. Cir. 1988).

170. See Simon \& Wagenhauser, supra note 189, at 200 (noting the number of newspapers, magazines, columnists, and politicians that came to Murdoch's defense). See also THE NEW Republic, Jan. 25, 1988, at 9 (defending Murdoch under the guise of increasing media competition). 
power. Unhappily, there is a serious shortage of criticism of corporate actions. This is not surprising given that corporations actively seek to influence the news content to ensure a favorable (or at least not unfavorable) public image ${ }^{171}$ and that corporations control most of the media.

Furthermore, although there is no shortage of reporting on politicians' personalities, sexual practices, drinking habits, and slips of the tongue, there is a serious shortage of reporting on substantive policies of the government. This was made painfully evident during the Reagan administration where there was little scrutiny of the administration's substantive policies. ${ }^{172}$ Indeed, the U.S. public did not learn of the administration's covert, illegal funding of aid to the Nicaraguan Contras until former U.S. Attorney General Ed Meese announced that funds obtamed from selling arms to Iran were channeled to the Contras. ${ }^{173}$ More generally, the U.S. press has been reluctant to challenge basic political norms such as the merits of remaining a nilitary superpower, engaging in covert activities, or basing a foreign policy on short-term strategic interests. ${ }^{174}$

Value three, the forum for public expression, has also not been served well by the American press system. In addition to the commodity nature of the media excluding, de facto, the voices of the nonaffluent from the media, ${ }^{175}$ the American press also suffers from the affliction of a "mass media mentality". ${ }^{176}$ Jean d'Arcy, a French communications theorist, describes this mentality as one that reduces niass communication in a society to "a vertical, one-way flow from the top downwards of nondiversified, anonymous messages, produced by a few and addressed to all."177 Indeed, this observation is a more cutting criticism of the American media than Bagdikian's study on media monopolies. There still are a nuniber of media voices in the United States not controlled by business conglomerates. However, with the possible exception of certain talk radio programs that carry live call-in shows permitting members of the public to express their views on the air, few of these media voices promote a two-way process of communication. ${ }^{178}$

Unfortunately, as d'Arcy points out, this one-way top-bottom flow

171. B. BAGDIKIAN, supra note 125 , at $46-66$ (describing various means used by corporations to prevent critical coverage).

172. See M. HERTSGAARD, supra note 3 .

173. N.Y. Times, Nov. 26, 1986, at A1, col. 1.

174. See Mother JoNES, supra note 3.

175. See supra notes $163-65$ and accompanying text.

176. See d'Arcy, The Right To Communicate, in CRISIS IN INTERNATIONAL NEwS, supra note 29 , at $122-23$.

177. Id.

178. Of course most newspapers and magazines print letters to the editor. However, not much space is provided for this section and editors tend to give preference to journalists, academics, and others with some professional connection to a topic covered by the periodical. 
of communication has become so entrenched in the United States that it would be virtually impossible in this country to move toward a more decentralized, interactive approach. ${ }^{179}$ In contrast, because of the inchoate nature of their media systems, most Third World nations are in the position to develop a more interactive press. Accordingly, Americans should recognize that, at least in western countries, the free-market model has failed for the most part in attaining an interactive media; hence, they should at least support those NIIO proposals that advocate increased access for individuals to the channels of mass communications, not just to professional journalists, editors, and owners of the media. ${ }^{180}$

\section{b. Does the American Model Further the Values of a Free Press in the Third World?}

Notwithstanding that large corporations control much of the mass media in the United States, nonmainstream and dissenting viewpoints still have access to certain opinion magazmes, commumity weeklies, and listener-supported radio stations. Furthermore, even some of the major newspapers will occasionally run a column by someone out of the mainstream. ${ }^{181}$ In many of the Third World countries where the media is privately rnn, the situation is much worse. For example, most of Latin America has private ownership of the press which has resulted in severe concentration of ownership. ${ }^{182}$ Due to the great poverty there, the nonelite have too little capital and political power to obtain even the limited alternative media that the nonelite have attained in the United States. To make matters worse, the private interests that control the Latin American media are often not indigenous, but come from the United States. ${ }^{183}$ Hence, the press does not even serve an indigenous elite but rather a foreign elite.

For most Third World countries then, the American model does not serve any of the functions of a free press. It does not report on matters of interest to the people in the country; it does not monitor the imstitutions running the society, including U.S.-owned institutions; and it does not serve as a public forum for free expression, but rather serves as a forum for a largely foreign elite.

179. D'Arcy, supra note 176 , at 133.

180. One of the principles set forth in the 1980 UNESCO General Conference Resolution was "respect for the right of the public, of ethnic and social groups and of individuals to have access to information sources and to participate actively in the communication process." A. MEHRA, supra note 7 , at 46 (footnote omitted).

181. For example, Alexander Cockburu, an avowed socialist, has a column that runs every third Thursday in the Wall Street Jourual.

182. Chin-Chuan Lee, supra note 51, at 93-94.

183. Beltran \& Fox de Cardona, supra note 39, at 34-38 (describing how U.S. interests dominate the Latin American media through direct investment in the Latin American media and financing of their media through advertising revenues). 


\section{Government Intervention is Needed in Many Developing Countries to Establish a Free Press}

If Third World countries adhere to the American prohibition against any government involvement in the media, they will have little power to alter the one-way flow in the international media or to structure their media systems to give access to all segments of the nation. ${ }^{184}$ In contrast to the paradigm of press freedom in the United States-where a privately-run press is supposed to guard against government abuse of power-for many developing countries, strong government support is required both to finance a press and to prevent its domination by indigenous and/or foreign business interests.

To achieve press freedom, however, the developing countries will need to be vigilant against the possibility of government involvement or sponsorship of the press deteriorating into government control of the press. Just as domination by large corporations is incompatible with a free press, so too is domination by the government. Hence, government involvement should be directed toward the goal of a plurality of indigenous media voices.

The use of government to ensure a plurality of media voices should not appear particularly offensive to Americans. Even in the United States, the government has not always looked the other way at media concentration. The FCC has promulgated a number of rules to encourage diversity of ownership in the media. ${ }^{185}$ If government intrusion into private ownership of the media has been viewed at times as necessary to maintain a free press in the United States, western defenders of a privately owned press should concede that government involvement is not always incompatible with a free press.

\section{CONCLUSION}

Although U.S. reaction to the NIIO has been ethnocentric, self-serving, and shortsighted, the proper response is not a blanket endorsement of the NIIO. This Comment does not advocate a specific response to the Third World countries' call for a NIIO but rather urges the U.S. to adopt a broader and more progressive framework for evaluating the NIIO. Withdrawing from UNESCO is no answer. The United States cannot end the debate or suppress Third World demands for international reform in the current information structure by ignoring them. The

184. As Schiller forcefully points out, "[w] freedom to continue doing what led to the existing condition-serves to strengthen the already powerful and weaken further the already frail." Schiller, supra note 88, at 183.

185. See, e.g., Citizens Communication Center v. FCC, 447 F.2d 1201, 1207 (D.C. Cir. 1971) ("Diversifieation of control of the media of mass communication is elevated ... to a factor of primary significanee [when the FCC is determining granting of radio licenses.]"). 
importance of the media is too great for Third World countries to stop pursuing redistributive changes in the international information order.

An appropriate framework for evaluating the NIIO should consist of the following primciples: Recognition of the great importance of the media in shaping and advancing a country's development; a progressive needs-based foreign aid policy; a commitment to rectifying the imbalance in information resources between developing and developed countries; and encouragement of all governments to recognize the underlying values represented by a free press along with an acknowledgement that these values do not necessitate a private press.

Finally, it should be stressed, that in encouraging other nations to recognize certain fundamental human rights such as freedom of expression and freedom of the press, the Umited States must be careful to prevent this encouragement from deteriorating into intervention in the general affairs of another country. For example, while the Umited States should encourage all Central American countries, including Nicaragua, to allow dissenting voices in the press, it would amount to unjustified intervention for the United States or its multinational corporations to dominate-or seek to dommate- the affairs of another country as they have done in the past with respect to Nicaragua and other Central American countries. Encouraging recognition of human rights does not mean demanding that countries replicate the American channel for recognizmg these fundamental rights. With respect to the underlying values found in a free press, the United States should work with the international community in getting all countries to recognize these values.

Of course, there will be difficult choices to make. Often, the principles outlined here will conflict with each other. Many authoritarian Third World governments are not about to recognize the values of allowing free expression and dissent. Yet, if the United States refuses to assist these nations in developing their own media, it may obstruct positive developments such as economic advancenent. Thus, just as imposing economic sanctions against other countries for the practices of their governments can end up hurting their poor citizens the most, so might refusing to give assistance to a developing country's communication system. The United States will have to decide which principle is the most important on a case-by-case basis. However, the United States should decide these questions on the basis of balancing the developing country's overall welfare against the value of a free press, not on what is in the short term-strategic interests of the United States. 
